\title{
Stability Assessment of Cephradine Suspension Formulated in Bangladesh
}

\author{
M. Z. Sultan ${ }^{\mathrm{a}}$, M. A. Mazid ${ }^{\mathrm{b}}$, and M. A. Rashid ${ }^{\mathrm{b} *}$ \\ ${ }^{a}$ Drug Research Laboratory, Centre for Advanced Research in Sciences, University of Dhaka, \\ Dhaka-1000, Bangladesh \\ ${ }^{b}$ Department of Pharmaceutical Chemistry, Faculty of Pharmacy, University of Dhaka, Dhaka-1000, \\ Bangladesh
}

Received 7 February 2011, accepted in final revised form 3 April 2011

\begin{abstract}
Cephradine, one of the commonly used and widely prescribed antibiotics in Bangladesh, is usually formulated in the dosage forms of capsule, dry suspension and IV injection. The dry-suspension is instructed to re-disperse in pre-boiled cooled water before use. A reversed phase high performance liquid chromatographic method (HPLC) has been developed for determination of cephradine in pharmaceutical preparation. To study the stability of cephradine suspension formulated by Bangladeshi manufacturers in aqueous medium and buffer of different $\mathrm{pHs}$ at room temperature, a simple and rapid chromatographic method was developed using acetonitrile and monobasic sodium phosphate buffer as mobile phase in the ratio of 15:85 (v/v) over C-8 bonded silica at ambient temperature using a flow rate of $1.0 \mathrm{~mL} / \mathrm{min}$. The study revealed that the potency of cephradine suspension was almost stable at room temperature up to 13 days in aqueous medium at $\mathrm{pH}$ between 4 and 5 .
\end{abstract}

Keywords: Cephradine; Suspension; HPLC; Potency; pH.

(c) 2011 JSR Publications. ISSN: 2070-0237 (Print); 2070-0245 (Online). All rights reserved.

doi:10.3329/jsr.v3i2.7024 J. Sci. Res. 3 (2), 383-391 (2011)

\section{Introduction}

Cephradine $\quad\left(\mathrm{C}_{16} \mathrm{H}_{19} \mathrm{~N}_{3} \mathrm{O}_{4} \mathrm{~S}\right) \quad$ is $\quad(6 R, 7 R)-7-[(R)-2-$ amino-2-(1,4-cyclohexadien-1yl)acetamido]-3- methyl-8-oxo-5-thia-1-azabicyclo[4.2.0]oct-2-ene-2-carboxylic acid which is a first generation antibiotic of the semisynthetic cephalosporin series [1-3]. Cephradine is a broad spectrum bactericidal antibiotic active against both gram-positive and gram-negative bacteria. It is also highly active against most strains of penicillinase producing Staphylococci [4-6]. The antibiotic is indicated in the treatment of communityacquired infections such as pharyngitis, otitis media, bronchitis, and skin as well as uncomplicated urinary tract infections [7, 8]. Cephradine is usually prescribed in the treatment of infections caused by sensitive organisms such as upper respiratory tract

\footnotetext{
*Corresponding author: rashidma@univdhaka.edu; rashid_phdu@yahoo.com
} 
infections e.g. pharyngitis, sinusitis, otitis media, tonsilitis, laryngotracheo-bronchitis; lower respiratory tract infections e.g. acute and chronic bronchitis and bronchopneumonia; urinary tract infections e.g. cystitis, urethritis, pyelonephritis; skin and soft tissue infections e.g. abscess, cellulitis, furunculosis; gastrointestinal tract infections e.g. bacillary dysentery, enteritis, peritonitis as well as bone and joint infection [9]. This antibiotic is also used for prophylaxis in certain surgical procedures to reduce the risk of post-operative infections $[10,11$.$] . It is widely used because of its extensive medical$ applications.

Cephradine is available in different dosage forms such as capsule, dry suspension and IV injection. According to the previous reports, cephradine itself tends to be quite stable at $\mathrm{pH} 4$ [12, 13], but it is extremely important to know the compatibility of the drug and its excipients in formulation which may impart the stability and effectiveness of the drugs [14]. It is also noted that the excipients may be different from different manufacturers which may affect the stability. This paper describes quantitative assay of cephardine along with assesment of potency of a cephradine suspension formulated in Bangladesh at different days and in buffer of different pHs at room temperature. To study the stability of cephradine, a simple, precise, accurate, reproducible and less time consuming HPLC method was also developed. From our study, we observed that the potency of cephradine is almost stable $\mathrm{pH}$ between 4 and 5. To the best of our knowledge, there was no previously published report in the literature about this type of study on cephradine suspension formulated in Bangladesh.

\section{Experimental}

\subsection{Materials and reagents}

Working standard of cephradine obtained from NCPC Beta Co. Ltd., China with a potency of $94.64 \%$ was a kind gift of Amico Pharmaceuticals Ltd., Bangladesh. For the estimation of cephradine in suspension, dry syrup samples were purchased from different manufacturers on random basis from retail pharmacies and coded as S-1, S-2 and S-3. HPLC grade sodium dihydrogen phosphate $\left(\mathrm{NaH}_{2} \mathrm{PO}_{4}\right)$, and acetonitrile were procured from local market.

\subsection{Apparatus}

\section{HPLC system}

High Performance Liquid Chromatographic system (Shimadzu-UFLC Prominence), equipped with an auto sampler (Model- SIL 20AC HT) and UV-Visible detector (ModelSPD 20A) was used for the analysis. The data was recorded using LC-solutions software.

\section{Column}

Analytical reversed phase C-8 column (Luna C-8(2), $5 \mu, 150 \times 4.6 \mathrm{~mm}$, Phenomenex, Inc.) was used to analyze the samples. 


\section{Preparation of buffer}

Monobasic sodium phosphate $\left(\mathrm{NaH}_{2} \mathrm{PO}_{4}, 97.6 \mathrm{mg}\right)$ was dissolved in $500 \mathrm{~mL}$ of nanopure water and sonicated for 10 minutes. The $\mathrm{pH}$ of the buffer was adjusted to 2.6 with phosphoric acid, and then it was filtered through a $0.45 \mu \mathrm{m}$ filter tips.

\section{Chromatographic conditions}

All analyses were done at ambient temperature $\left(25 \pm 2{ }^{\circ} \mathrm{C}\right)$ under isocratic conditions. The mobile phase contained acetonitrile and monobasic sodium phosphate buffer in the ratio of 15:85 (v/v). Flow rate was kept at $1.0 \mathrm{~mL} / \mathrm{min}$. The injection volume was $20 \mu \mathrm{L}$ for standard and samples. Before analysis, every standard and sample were filtered through $0.45 \mu \mathrm{m}$ filter tips. The mobile phase (acetonitrile and buffer) was also filtered, sonicated and degassed before use. The column eluate was monitored at $255 \mathrm{~nm}$.

\section{Preparation of standard solutions}

Solution of the standard drug was prepared by dissolving $5.28 \mathrm{mg}$ of microcrystallines cephradine (equivalent to $5.0 \mathrm{mg}$ cephradine) in a $10 \mathrm{~mL}$ volumetric flask using $5 \mathrm{~mL}$ of buffer. Then the volume was made up to the mark with the same buffer. The final concentration was obtained $0.5 \mathrm{mg} / \mathrm{mL}$. Appropriate volume from this solution was further diluted to get standards of varying concentrations $(10,25,50,100,250,500$ $\mu \mathrm{g} / \mathrm{mL})$.

\section{Preparation of test sample}

A suitable amount of dry syrup used for preparing suspension equivalent to $100 \mathrm{mg} / \mathrm{mL}$ of cephradine was prepared by adding boiled and cooled drinking water as per instructions of the manufacturer. The mixture was shaken continuously until the powder was dissolved properly. The mixture was shaken well before each use. This suspension was marked as test sample and kept at normal temperature $\left(25 \pm 2{ }^{\circ} \mathrm{C}\right)$.

\subsection{Method of validation $[1,15-17]$}

\section{Accuracy}

To evaluate the accuracy of the proposed method, successive analysis $(n=3)$ for three different concentrations ( $500 \mu \mathrm{g} / \mathrm{mL}, 250 \mu \mathrm{g} / \mathrm{mL}$ and $100 \mu \mathrm{g} / \mathrm{mL}$ ) of standard cephradine solution were carried out using the proposed method. The accuracy was confirmed by calculating the percent recovery (R\%) from the mass added and mass found.

\section{Precision}

The precision was checked by intra- and inter-day repeatability of responses after replicate injections of two standard solutions (500 $\mu \mathrm{g} / \mathrm{mL}$ and $600 \mu \mathrm{g} / \mathrm{mL}$ ). The precision was expressed as RSD \% amongst responses using the formula [RSD (\%) = (Standard deviation/Mean) x $100 \%]$. 


\section{Calibration curves}

Four different concentration levels (5.0, 10.0, 25.0 and $50.0 \mu \mathrm{g} / \mathrm{mL})$ were prepared from standard solution by diluting with the mobile phase. Then $20 \mu \mathrm{L}$ from each solution was injected into the HPLC using auto-sampler and the analyses were monitored at $255 \mathrm{~nm}$. The peak areas were plotted against concentrations.

\section{Linearity}

The linearity of the proposed method was evaluated by using calibration curves to calculate coefficient of correlation and intercept values.

\subsection{Assay}

Assay of suspension at same $\mathrm{pH}$ on different days

From each of the test suspensions, required volume of cephradine suspension was taken in a $10 \mathrm{~mL}$ volumetric flask after properly shaking, $5 \mathrm{~mL}$ of monobasic sodium phosphate buffer at $\mathrm{pH} 2.6$ was added and sonicated to dissolve. The volume was made up to the mark by adding buffer and mixed well to get a solution of cephradine concentration of $500 \mu \mathrm{g} / \mathrm{mL}$. Then it was filtered through $0.45 \mu \mathrm{m}$ syringe filter tip and analyzed by injecting $20 \mu \mathrm{L}$ of each sample by HPLC. The experiment was done twice on a day and repeated on $1,2,4,5,6,8,9,11,14$, and $15^{\text {th }}$ days. The average drug content of the suspensions was determined using the calibration curve.

\section{Assay of suspension at various $\mathrm{pHs}$ on different days}

Eight flasks containing about $75 \sim 100 \mathrm{~mL} \mathrm{NaH} \mathrm{PO}_{4}$ buffer were taken and $\mathrm{pH}$ of the buffers were adjusted to 1, 2, 3, 4, 5, 6, 7, and 8 with phosphoric acid and $\mathrm{NaOH}$. Eight 10 $\mathrm{mL}$-volumetric flasks were taken and marked according to the $\mathrm{pH}$ of the flasks. Aliquots of $250 \mu \mathrm{L}$ cephradine suspension was taken in each volumetric flask and mixed with about $5 \mathrm{~mL}$ of respective buffers. Then the volume was adjusted up to the mark by adding the same buffer to get various pHs in different flasks at $0.5 \mathrm{mg} / \mathrm{mL}$. All the buffers containing cephradine were kept at room temperature $\left(25 \pm 2{ }^{\circ} \mathrm{C}\right)$. Then the samples were analyzed with HPLC on $1,4,6,8,11$ and $15^{\text {th }}$ days after filtering through $0.45 \mu \mathrm{m}$ syringe filter tips.

\section{Results and Discussion}

A reversed phase HPLC method has been developed and validated for determination of cephradine in suspension made from dry syrups using the mobile phase containing acetonitrile and monobasic sodium phosphate buffer in the ratio of 15:85 (v/v) at ambient temperature at flow rate of $1.0 \mathrm{~mL} / \mathrm{min}$ with UV detection at $255 \mathrm{~nm}$. The injection volume was kept at $20 \mu \mathrm{L}$ for standard and all samples. The retention time of cephradine was found to be $5.50 \pm 0.1 \mathrm{~min}$ (Fig. 1). The method was validated to ensure selectivity, accuracy and precision and linearity. 


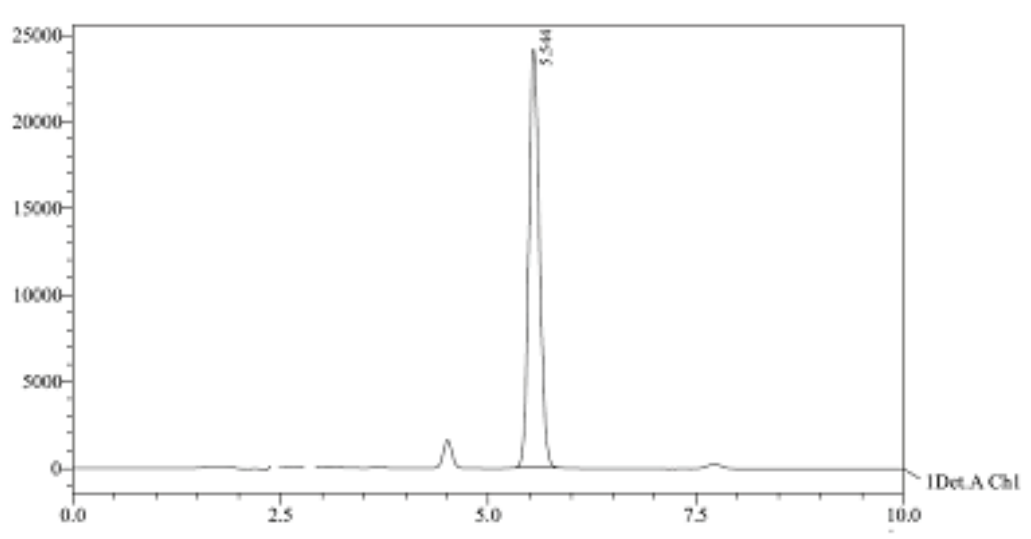

Fig. 1. HPLC chromatogram of cephradine.

Accuracy studies of the drug were carried out at three concentration levels of standard and three replicate measurements were recorded at each concentration level. The results were recorded as percentage of mean recovery with standard deviation (SD) and was found to be within the limits (Table 1).

Table 1. Accuracy of the developed method.

\begin{tabular}{ccccc}
\hline $\begin{array}{c}\text { Injected } \\
\text { cephradine } \\
(\mu \mathrm{g})\end{array}$ & $\begin{array}{c}\text { Recovered } \\
\text { cephradine } \\
(\mu \mathrm{g})\end{array}$ & $\begin{array}{c}\text { Recovered } \\
\text { cephradine } \\
(\%)\end{array}$ & $\begin{array}{c}\text { Mean } \\
\text { recovery } \\
(\%)\end{array}$ & SD \\
\hline 500 & 501.77 & 100.35 & & \\
$(\mathrm{n}=3)$ & 498.90 & 99.78 & 100.26 & \pm 0.173 \\
& 503.27 & 100.65 & & \\
250 & 251.85 & 100.74 & & \\
$(\mathrm{n}=3)$ & 252.40 & 100.96 & 100.87 & \pm 0.112 \\
& 252.23 & 100.89 & & \\
100 & 99.62 & 99.62 & & \\
$(\mathrm{n}=3)$ & 99.70 & 99.70 & 99.28 & \pm 0.664 \\
& 98.51 & 98.51 & & \\
\hline
\end{tabular}

Precision was checked at two concentration levels, using five replicate measurements at each concentration level on the same day and different days, and it was expressed as relative standard deviation (RSD). The results are summarized in Table 2. The calculated relative standard deviations were obtained as 1.35 and 1.12 which were less than the maximum allowed limit $[15,16,18,19]$. The results of accuracy and precisions studies indicated good sensitivity of the proposed method. 
Table 2. The precision of the developed method.

\begin{tabular}{ccc}
\hline $\begin{array}{c}\text { Injected cephradine } \\
(\mu \mathrm{g})\end{array}$ & $\begin{array}{c}\text { Mean recovered } \pm \text { SD } \\
(\mathrm{n}=5)\end{array}$ & RSD \% \\
\hline 500 & $504.29 \pm 6.83$ & 1.35 \\
600 & $603.14 \pm 6.75$ & 1.12 \\
\hline
\end{tabular}

When peak area $(y)$ was plotted against concentration (c), a good correlation coefficient was obtained in concentration range of 5.0, 10.0, 25.0 and $50.0 \mu \mathrm{g} / \mathrm{mL}$. For the equation of calibration curve correlation co-efficient $\left(r^{2}\right)$ was obtained as 0.999 which indicated excellent linearity of the newly developed method (Fig. 2).

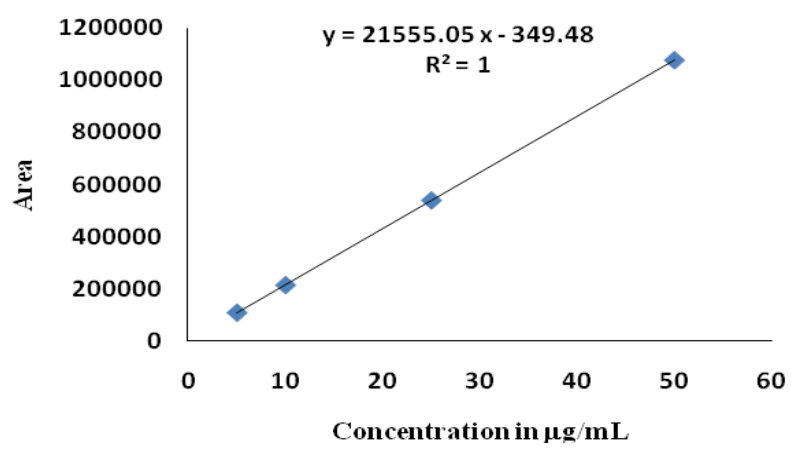

Fig. 2. Linearity curve of cephradine.

This method was applied to study of the stability of cephradine suspensions formulated by Bangladeshi manufacturers in aqueous medium and in buffer of different pHs at room temperature.

Cephradine for oral suspension is a dry mixture of cephradine and one or more suitable buffers, colors, diluents, and flavors. It contains not less than $90 \%$ and not more than $125.0 \%$ of the labeled amount of cephradine, calculated as the sum of cephradine and cephalexin $\left(\mathrm{C}_{16} \mathrm{H}_{17} \mathrm{~N}_{3} \mathrm{O}_{4} \mathrm{~S}\right)$ [1]. According to the United States Pharmacopoeia (USP), cephalexin present in cephradine should not be more than $5.0 \%$ and the potency of cephradine preparations was calculated as the sum of cephradine and cephalexin. But in our study we ignored the potency of cephalexin.

The $\mathrm{pH}$ of the suspension after adding the normal drinking water was found as 4.7 which was supported by the monograph [1]. The $\mathrm{pH}$ was almost stable at $4.7 \pm 0.1$ up to the $14^{\text {th }}$ day and the slight variation did not affect the potency of cephradine. It was found that the potency of the suspension at room temperature gradually decreased in the range of 
104.1 to $93.3 \%$ from 1 to $11^{\text {th }}$ days (Fig. 3), which was within the limits of USP. But on the $14^{\text {th }}$ day, the cephradine content in the suspension was below the lower limit of the USP and the potency was found as $89.6 \%$. The decrease in potency at room temperature on $14^{\text {th }}$ day did not hamper the use of the suspension, because it can be used up to $7^{\text {th }}$ day by the patient if kept it at room temperature and up to $14^{\text {th }}$ day if kept in refrigerator as directed in the label of the manufacturers. This potency parameter showed that the cephradine formulated in Bangladesh is adequate.

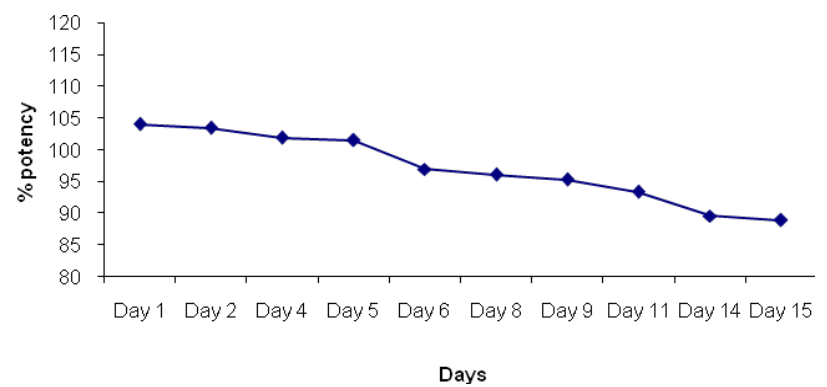

Fig. 3. Stability of cephradine suspension on different days

To study the stability of the cephradine suspension in the buffer of different pHs, we used monobasic sodium phosphate buffer of the $\mathrm{pH}$ as 1, 2, 3, 4, 5, 6, 7 and 8 adjusted by phosphoric acid or sodium hydroxide. The experiment revealed that the average potency of cephradine suspension was quite stable and maximum at $\mathrm{pH} 4$ and $\mathrm{pH} 5$ throughout the study period and was found as 109.5 and 106.4 on day $1 ; 109.5$ and 106.3 on day 4 ; 106.3 and 103.2 on day 6; 102.1 and 101.0 on day 8; 100.5 and 99.5 on day 11; and 94.5 and 93.1 on day 15, respectively (Fig. 4). Cephradine was quite unstable and rapidly degraded in alkaline conditions and potency also declined at strongly acidic conditions. These results were almost similar with the previously reported data [12] with some exception described in the assay of cephradine itself without any excipient as well as did not report the stability at $\mathrm{pH} 5$.

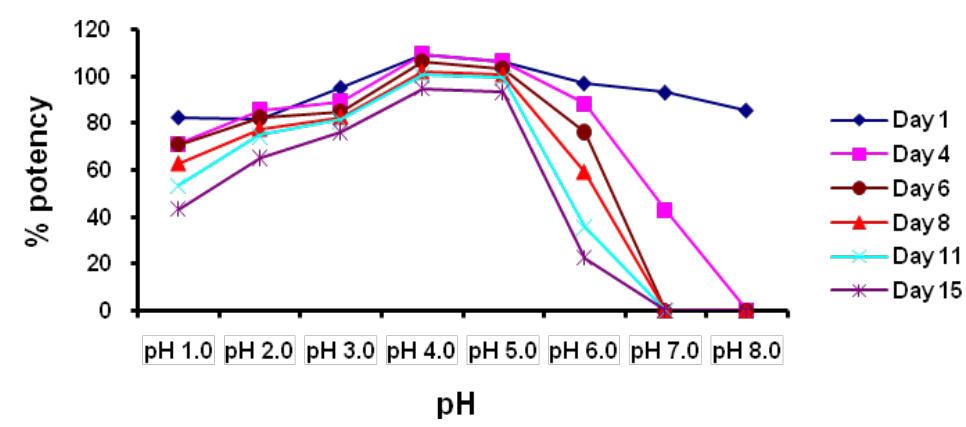

Fig. 4. Stability of cephradine suspension at different $\mathrm{pH}$. 


\section{Conclusion}

Since the excipients in the formulation may have an important effect on stability and effectiveness of the drugs at room temperature, we studied the stability of the suspension formulated in Bangladesh in aqueous medium and in buffer of different pHs at room temperature. From our study we can conclude that the potency of cephradine formulation is quite stable between $\mathrm{pH} 4$ and 5 . It was also found that the potency of the suspension at room temperature gradually decreased. For quantitative determination of cephradine in aqueous suspension or buffer we also developed a reversed phase HPLC method which was found to be simple, precise, accurate, reproducible and less time consuming.

\section{References}

1. United States Pharmacopoeia 30 - National Formulary 25 (USP 30 - NF 25), United States Pharmacopeial Convention, Rockville, MD (2007).

2. British Pharmacopoeia (BP)-2009 (The Stationary Office, London, 2002).

3. I. Weliky, H. H. Gadebusch, K. Kripalani, P. Arnow, and E. C. Schreiber, Antimicrob. Agents Chemother. 5, 49 (1974). PMid:4840449 PMCid:428917

4. M. K. Hassanzadeh, S. F. Bazzaz, and S. Afzali, DARU 7 (4), 15 (1999).

5. M. H. Shoaib, D. Shaikh, R. I. Yousuf, B. S. Naqvi and K. Hashmi, Pak. J. Pharm. Sci. 21 (4), 400 (2008). PMid:18930862

6. A. Zaki, E. C. Schreiber, I. Weliky, J. R. Knill, and J. A. Hubsher, J. Clin. Pharmacol. 14, 118 (1974). PMid:4591487

7. J. C. Fung-Tomc, E. Huczko, T. Stickle, B. Minassian, B. Kolek, K. Denbleyker, D. Bonner and R. Kessler, Antimicrob. Agents Chemother. 39, 533 (1995). PMid:7726528 PMCid:162574

8. D. L. Caloza JR., R. W. Semar and G. E. Bernfeld, Antimicrob. Agents Chemother. 15, 119 (1979). PMid:426499 PMCid:352609

9. R. Wisebritish, Br. Med. J. 2, 40 (1978). doi:10.1136/bmj.2.6129.40

10. Remington, The Science and Practice of Pharmacy, $19^{\text {th }}$ edition, Vol. II (Mack Publishing Company, Easton, Pennsylvania, USA, 1995) pp. 1290-1291.

11. M. Ahmad, M. Usman, A. Madni, N. Akhtar, N. Khalid, W. Asghar, and S. Bakhsh, J. Chem. Soc. Pak. 32, 58 (2010).

12. K. Florey (Editor), Analytical profiles of drug substances, Vol. V (Academic Press, Inc., New York, 1976) pp. 46-47.

13. T. Yamana and A. Tsuji, J. Pharm. Sci. 65, 1563 (1976). doi:10.1002/jps.2600651104

14. J. W. Collier, R. B. Shah, A. Gupta, V. Sayeed, M. J. Habib, and M. A. Khan, AAPS Pharm. Sci. Tech. 11, 818 (2010). doi:10.1208/s12249-010-9434-8

15. USA Food and Drug Administration, Methods, method verification and validation; Document No. ORA-Lab. 5.4.5, Version No. 1.5 (2009).

16. International Conference on Harmonization: ICH Harmonized Tripartite Guideline- Validation of Analytical Procedures: Text and Methodology Q2(R1): 2005.

17. B. M. M. A. Razib, M. A. Ullah, M. A. K. Azad, R. Sultana, H. Yasmin and A. Hasnat, Dhaka Univ. J. Pharm. Sci. 5, 1 (2006).

18. V. Ravichandran, S. Shalini, K. M. Sundram, and H. Rajak, Int. J. Pharm. Pharm. Sci. 2 (suppl 3), 18 ( 2010). 
19. A. M. Qandil, B. M. Tashtoush, B. M. Al-Taani, S. M. Al-Nabulsi, and F. Al-Zogoul, Chromatographia 67, 287 (2008). doi:10.1365/s10337-007-0482-5 